дження, та характерних для всіх або більшості кримінальних справ безвідносно до кримінально-правової кваліфікації досліджуваної події, що традиційно кладеться в основу створення окремих криміналістичних методик.

Такими в загальних рисах $є$ основні приписи, якими повинен керуватися розробник окремих судових методик. Серед них законність, теоретична обгрунтованість та практична застосовність, конкретність, оперативність, планомірність (етапність), ситуаційна обумовленість. Зрозуміло, що ними не вичерпується вся системи засад створення та функціонування таких побудов. Це швидше той обов'язковий мінімум правил, яким вони мають відповідати. Вочевидь при більш глибокому спеціальному дослідженні можуть бути названі й інші принципи створення окремих методик судового провадження та запропоновані їх класифікаційні системи.

\title{
Література:
}

1. Журавель В. Окрема криміналістична методика: поняття та сфера застосування. Вісник Академї̈ правових наук України. 2011. № 2. С. 202213.

2. Мишин А.В. Особенности криминалистической деятельности в судебном производстве по уголовным делам. Ученые записки Казанского университета. Гуманитарные науки. 2017. Т. 159. Кн. 2. C. 504-511.

DOI https://doi.org/10.30525/978-9934-26-148-0-44

\section{ЗАХИСТ ІНФОРМАЦЇ̈, ОТРИМАНОЇ В РЕЗУЛЬТАТІ ПРОВЕДЕННЯ НЕГЛАСНИХ СЛІДЧИХ (РОЗШУКОВИХ) ДІЙ}

\author{
Цилюрик I. I. \\ кандидат юридичних наук, \\ дочент кафедри кримінального права і прочесу \\ Навчально-наукового Інституту права, психології \\ та інноваційної освіти Національного університету \\ «Львівська політехніка» \\ м. Львів, Украӥна
}

Інформацію, яка отримана в результаті НСРД можна розподілити на дві групи:

- інформація, яка використовується у кримінальному провадженні; 
- інформація, яка не використовується у кримінальному провадженні.

Залежно від належності інформації до певної групи різними $є$ способи захисту отриманої інформації. Заходами захисту інформації, що використовується у кримінальному провадженні є:

1) заборона розголошувати відомості про факт та методи НСРД і інформацію, отриману в результаті їх проведення;

2) якщо є інформація про приватне життя інших осіб, то захисник та інші учасники, що мають право на ознайомлення 3 протоколами, попереджаються про кримінальну відповідальність та розголошення;

3) виготовлення копій протоколів НСРД і додатків до них не допускається.

Оскільки відомості про факт і методи проведення НСРД не підлягають розголошенню, постанова слідчого, прокурора про проведення НСРД, клопотання про дозвіл на проведення НСРД, ухвала слідчого судді про дозвіл на проведення НСРД та додатки до нього, протокол пр. проведення НСРД, які містять відомості про факт та методи проведення НСРД, а також відомості, що дають змогу ідентифікувати особу, місце або річ, щодо якої проводиться або планується проведення такої дії, розголошення яких створює загрозу національним інтересам та безпеці, підлягають засекречуванню [1, с.103].

Засекречування цих документів здійснюється слідчим, прокурором, співробітником уповноваженого оперативного підрозділу, слідчим суддею шляхом надання відповідному документу грифа секретності. На практиці в більшості випадків гриф таємності присвоюється документам, пов'язаним з НСРД, виключно виходячи 3 того, що сам факт їх проведення підлягає збереженню таємниці [2, с. 56]. Така позиція грунтується на положеннях ч. 1 ст. 246 КПК, якою визначено, що заборона розголошення факту проведення $\epsilon$, поряд 3 методикою проведення, головною ознакою НСРД [3].

Інформація про методи проведення НСРД може становити державну таємницю й міститись у деяких протоколах, на електронних носіях. Однак сам факт проведення таких дій, що фіксується у постанові про проведення НСРД, клопотанні про надання дозволу, дозволі суду, не розкриває методику їх проведення та не стосується національних інтересів та безпеки. Обмеження доступу до такої інформації та обмеження ії розповсюдження має забезпечуватись з урахуванням вимог статей 381, 387 КК України [4].

Тому, на нашу думку, з метою обмеження доступу до інформації у кримінальному провадженні доцільніше попереджувати осіб про відповідальність за розголошення даних досудового розслідування, 
аніж проводити громіздку процедуру щодо присвоєння та зняття грифа таємності чи допуску учасників кримінального провадження до державної таємниці, оскільки КПК, Закон України «Про державну таємницю» не містять заборони для прийняття такого рішення [2, с. 58].

Забезпечення охорони державної таємниці та дотримання інших вимог законодавства про державну таємницю при проведенні НСРД покладається на слідчих, прокурорів, слідчих суддів та співробітників уповноважених оперативних підрозділів, які виконують НСРД.

Після завершення НСРД грифи секретності підлягають розсекреченню на підставі рішення прокурора, який здійснює повноваження прокурора в конкретному кримінальному провадженні у формі процесуального керівництва досудовим розслідуванням, 3 урахуванням обставин кримінального провадження та необхідності використання матеріалів НСРД як доказів після проведення таких дій, якщо витік зазначених відомостей не завдасть шкоди національній безпеці України.

Таке рішення оформляються постановою прокурора, який здійснює повноваження прокурора в конкретному кримінальному провадженні у формі процесуального керівництва досудовим розслідуванням, що погоджується керівником прокуратури. У даній постанові повинно бути вказано, яка НСРД проводилась, на якій підставі, яка інформація має значення для кримінального провадження, в якому обсязі вона буде розсекречена.

Після отримання клопотання про необхідність скасування грифів секретності щодо проведення НСРД та відповідних документів керівником органу, де здійснювалось їх засекречування, створюється експертна комісія з питань таємниці, якій доручається підготовка рішень про скасування грифів секретності. Результати засідань експертної комісії фіксуються у протоколі, в якому відображаються питання для обговорення та їх результати, запитання, зауваження та пропозиції членів комісії. Рішення комісії оформляється актом скасування грифу секретності, який затверджується керівником органу.

В органах прокуратури скасування грифів секретності щодо проведення НСРД здійснюється в тій прокуратурі, де засекречено такий носій інформації.

Після розсекречення зазначених носіїв інформації щодо проведення НСРД приймається рішення про їх зняття 3 обліку та доручення до матеріалів кримінального провадження у встановленому КПК порядку.

Про розсекречення інформації службова особа, яка його здійснила, зобов'язана письмово повідомити прокурора, якому такі носії секретної інформації або документи були передані. 
Розсекречену інформацію, яку прокурор має намір використати як доказ під час судового розгляду,зберігається на розсуд прокурора в його службовому сейфі чи в сейфі слідчого за вказівкою прокурора. До розсекречених матеріалів доступ надається разом з іншими матеріалами досудового розслідування в порядку ст. 290 КПК України [3].

Враховуючи наведену процедуру засекречування та розсекречування інформації, варто погодитися 3 думкою що, доцільно було б виробити диференційований підхід до забезпечення режиму таємності при організації та проведенні НСРД, деталізувавши його у відповідній інструкції, та ініціювати внесення змін до Закону України «Про державну таємницю».

У разі наявності в матеріалах щодо проведення НСРД відомостей, що становлять державну таємницю, досудове розслідування та судове провадження у кримінальному провадженні проводяться з дотриманням вимог режиму секретності та в порядку, передбаченому главою 40 КПК України [3].

Однак, як вірно зазначається в літературі, чинним законодавством не врегульовано питання щодо розсекречування рішень слідчих суддів апеляційних судів про надання дозволів на проведення НСРД. Зазначені рішення $\epsilon$ юридичною підставою для проведення більшості таких дій, а одержані внаслідок цього докази оцінюються судом 3 позиції допустимості під час розгляду справи по суті. Про те наказу або іншого документа ВССУ чи ВСУ з цього питання не існує, унаслідок чого судді не задовольняють письмові запити прокурорів щодо зняття грифа секретності з рішень слідчих суддів апеляційних судів.

\section{Література:}

1. Коробко Ю.В. Процесуальні повноваження прокурора у досудовому кримінальному провадженні: дис. канд. юрид. наук : 12.00.09 / Ю.В. Коробко, Нац. акад. прокуратури України. Київ, 2016. C. 103.

2. Бабіков О. Негласні слідчі дії: проблеми правового регулювання// Вісн. Національної академії прокуратури України. 2013. № 3. С. 56-58.

3. Кримінальний процесуальний кодекс України: чинне законодавство зі змінами та доповненнями № 4651 - VI станом на 08.08.2021 p. URL: https://zakon.rada.gov.ua/laws/show/4651-17\#Text. (дата звернення 18.09.2021 p.).

4. Кримінальний кодекс України: чинне законодавство зі змінами та доповненнями № 2341 - III станом на 08.08.2021 p. URL: https:// zakon.rada.gov.ua/laws/show/2341-14\#Text (дата звернення 18.09.2021 p.) 